\title{
Customer Satisfaction with Digital Wallet Services: An Analysis of Security Factors
}

\author{
Dewan Ahmed Muhtasim ${ }^{1}$, Siok Yee Tan², Md Arif Hassan ${ }^{3}$, Monirul Islam Pavel ${ }^{4}$, Samiha Susmit ${ }^{5}$ \\ Center for Artificial Intelligence Technology, Faculty of Information Science and Technology \\ Universiti Kebangsaan Malaysia, 43600 Bangi, Selangor, Malaysia ${ }^{1,2,4}$ \\ Center for Cyber Security, Faculty of Information Science and Technology \\ Universiti Kebangsaan Malaysia, 43600 Bangi, Selangor, Malaysia ${ }^{3}$ \\ Faculty of Information Science and Technology, Universiti Kebangsaan Malaysia, 43600 Bangi, Selangor, Malaysia ${ }^{5}$
}

\begin{abstract}
This study aimed to determine an efficient framework that caters to the security and consumer satisfaction for digital wallet systems. A quantitative online survey was carried out to test whether the six factors (i.e., transaction speed, authentication, encryption mechanisms, software performance, privacy details, and information provided) positively or negatively impact customer satisfaction. This questionnaire was divided into two sections: the respondents' demographic data and a survey on security factors that influence customer satisfaction. The questionnaires were distributed to the National University of Malaysia's professors and students. A sample of 300 respondents undertook the survey. The survey results suggested that many respondents agreed that the stated security factors influenced their satisfaction when using digital wallets. Previous studies indicated that financial security, privacy, system security, cybercrime, and trust impact online purchase intention. The proposed framework in this research explicitly covers the security factors of the digital wallet. This study may help digital wallet providers understand the customer's perspective on digital wallet security aspects, therefore motivating providers to implement appropriately designed regulations that will attract customers to utilize digital wallet services. Formulating appropriate security regulations will generate long-term value, leading to greater digital wallet adoption rates.
\end{abstract}

Keywords-Cashless transaction; electronic payment; internet security; consumer satisfaction; e-commerce

\section{INTRODUCTION}

A digital wallet platform allows individuals to perform electronic transactions using mobile devices, such as smartphones, computers, and other supporting devices. Digital wallets have multiple usages, including making purchases from websites or using mobile devices to make in-store transactions [1]. The current economy is transforming into a cashless economy where daily transactions are being performed using the digital wallet. Several e-commerce companies have developed digital wallet payment systems. The development of digitization through the internet has advanced the transition of globalization and payment systems from manual to online transactions. People have become more reliant on electronic money to perform transactions as a result [2].

The Malaysian government encourages people to go cashless and use digital wallets. A survey by Visa found that nearly half of Malaysians can live without cash. This study illustrated Malaysia's potential to evolve into a cashless society
[3]. The current advanced technologies make it easier for Malaysia to shift toward a cashless society. In support of Industry 4.0, Malaysia has taken significant initiatives to establish the status of a cashless society. According to FinTech News Malaysia's report, approximately $17 \%$ of the corporations in the Malaysian financial industry formed a sector to establish digital wallets [4]. Cashless transactions result in enhanced capability, transparency, and accountability [3].

Nevertheless, cybercrime cases still occur, and cases of internet security violations are frequent. Moreover, hackers and tricksters are prone to take advantage of such situations to damage companies and consumers [5]. Thus, customer satisfaction is greatly influenced by their perceptions of security and trust [6]. Customers in the e-banking industry are more advanced, knowledgeable, and demanding [7]. Companies and customers avoid e-commerce operations for several reasons, and security is one of the key reasons [8]. Therefore, security is a serious concern when performing financial transactions through digital transaction methods [9]. Moreover, electronic payment systems are currently facing many difficult hindrances posed by the internet. In comparison, the challenges faced by electronic payment systems are more complicated than the majority of internet security issues [10].

This work was supported by the Ministry of Higher Education Malaysia (FRGS/1/2018/ICT01/UKM/02/5) and Universiti Kebangsaan Malaysia (GUP-2020-060).

Financial services are extending their sector to include smartphones as electronic payment devices. Smartphones are popular banking, payment, budgeting, shopping, and stock trading applications for customers [11]. Due to the growth of the e-commerce industry, the electronic payment platform is becoming increasingly prominent and essential for smartphone users [12]. Smartphones and other electronic devices contain confidential information of their users, including transaction details and passwords. Consumers do not need to carry their wallets or purse while using digital wallets. However, they need to carry at least one electronic device, such as a smartphone or tablet. In the case of a stolen or lost device, the user risks losing personal and confidential information [13].

The digital wallet is still at its infancy stage in Malaysia as it is a newly introduced payment system. Electronic transactions are a safer mode for consumer payment, enabling 
sellers to enhance their productivity and increase profits [14]. Electronic transactions are traceable, whereas cash transactions are not traceable. Hence, the electronic payment system is a secure way of performing transactions. However, according to the latest VMware Banking User, a 2020 study shows that nearly half or $46 \%$ of Malaysian consumers are uncertain of digital wallet protection and payment applications [15]. Consumers are concerned about privacy and security threats due to the fear of data fraud and spam [16]. Security and privacy impose a significant and positive impact on behavioral intention when using digital payment services [17]. Therefore, e-retailers should concentrate on improving consumers' protection, loyalty, and purchase intent. They should also be attentive to enhanced security when developing a consumer privacy policy [18]. Hence, the security factors have a significant impact on consumer satisfaction toward digital in Malaysia. Therefore, security factors that can affect Malaysian customer satisfaction are required to be evaluated thoroughly. Ali et al [19]. The author in proposed a framework for the security factors that influence consumers in online shopping in Malaysia. It contains five security factors, financial security, privacy, system security, cybercrime, trust, and customer satisfaction. However, the research failed to identify the specific security factors of the digital wallet.

Nevertheless, limited study has been undertaken to identify the specific digital wallet security factors affecting customer satisfaction in Malaysia. This research proposes a framework for security factors that influence consumer satisfaction in Malaysian digital wallet platforms. This model consists of six security factors: transaction speed, authentication, encryption mechanisms, software performance, privacy details, and information provided. This model is created after studying numerous previous studies from similar fields [19], [20], [29], [30], [21]-[28].

This research introduces security factors to the digital wallet industry in Malaysia that impact customer satisfaction. Besides, this research can assist policymakers of digital wallet applications to concentrate on key security factors and improve platform security while developing security regulations, resulting in a higher rate of consumer adoption. In addition, the research also attempted to study students' and professors' usage and understanding of Malaysia's available digital wallet platforms. The respondents' demographics, comprising both genders, were the students and professors in the National University of Malaysia. They have used the digital wallet services at least once for online purchases. Students between the ages of 18 to 25 were the majority of the respondents.

This research aimed to discover the numerous security concerns that may arise while using digital wallet services for electronic payments besides investigating whether the proposed security factors (i.e., transaction speed, authentication, encryption mechanisms, software performance, privacy details, and information provided) affect the consumer's decision when choosing digital wallet services. This study also aimed to identify variables that have a higher effect on customer satisfaction.

This paper is divided into seven sections. Section 1 presents the introduction and scope of this study, whereas Section 2 reviews previous research on similar topics. In Section 3, the framework and hypothesis of this study are discussed. The methods and analysis techniques of the study are presented in Section 4. Findings of the analysis, the study's limitations, and the conclusions are discussed in Section 5, Section 6, and Section 7, respectively.

\section{LITERATURE REVIEW}

Digital wallet systems are developed to aid various functionalities. The functions of digital wallet systems are categorized into open digital wallets, semi-closed digital wallets, and closed digital wallet types. Mobile and wireless networking technology, such as smartphones, personal digital assistants (PDAs), and laptops, have eased customers' convenience in utilizing such devices to shop virtually via electronic transaction methods. Transactions are more accessible and transparent through this new method [31]. Nevertheless, several variables may impact the satisfaction of consumers toward electronic transactions. Security, privacy, confidence, and consistency significantly affect e-commerce consumers, among other factors [20]. Mobile perceived security risks determine the consumers' perception of security against conducting mobile transactions, especially the risk of losing important information, resulting in financial losses [32]. Customers' willingness to utilize mobile payment services is influenced by the ease of use, comparative advantage, clarity, and perceived protection.

Furthermore, prevalence and observability positively affect an individual's perception of security, whereas concerns about privacy threats negatively influence the perception [33]. Moreover, the continuous technological development and efforts to promote them are reasons for perceived security as one of the intentions to use digital wallets. Consumers would feel safer when using mobile payment if tools are available to protect the payment systems in unexpected incidences [34]. In an empirical study multiple variables were considered when studying consumer's perceived risk and their attitude toward online shopping in Malaysia. The researchers found that the consumer perceived risks negatively affect the consumer attitude, which positively and significantly affects online shopping behavior [35]. Content quality, peer influence, KOL influence, perceived interaction, effort expectation, and perceived trust all substantially impact users' intention to pay, and their tendency has an indirect impact on users' paying behavior [36].

Although the young generation's actual use of digital payments is driven by behavioral intention and promotional strategies, perceived risks are shown to have a negative effect [37]. Another empirical study asserted that customers were reluctant to use digital wallets when they assumed high perceived risk [11]. Moreover, the study also indicated that financial risks are one of the leading consumer perceived risks. Financial risks emerged as the most significant influence that adversely affects consumer attitude. One of the proposed ideas is to protect the consumers' personal information and decrease credit card fraud cases to minimize financial risks. Due to the risk factors, customers often opt-out from paying via their credit cards [35]. Many researchers concluded that security is a significant factor influencing customer satisfaction in online 
shopping [38]-[40]. A study found that behavioral intention to use digital wallets is strongly and vitally associated with perceived utility, perceived ease of use, and privacy and protection [21]. According to Peikari [24], security statements and technical protection significantly impact customer loyalty in the e-commerce industry but did not find a substantial effect on privacy.

Nevertheless, Barry and Jan [22] indicated that privacy and security positively correlate with behavior intention. Consumers may feel vulnerable to digital wallet transactions due to a lack of privacy and security. Nizam et al. [8] conducted empirical research to monitor digital wallets implementation in Malaysia. According to the study's findings, the dependent variable (customer purchasing decision using the digital wallet) is positively linked to all independent variables (convenience, security, and cost-saving).

Furthermore, convenience has the maximum significant positive correlation of 0.624 , whereas security showed the coefficient correlation of 0.4999 with customer buying decisions using digital wallets. Based on the analysis, it was concluded that security has a more significant positive association with digital wallets for customer purchase behavior. In addition, Razif et al. [23] conducted empirical research among Malaysian young adults between 18 and 30 years old. The study showed that several factors have a significant relationship with the acceptance of the digital wallet platform. The factors listed were behavioral intention, perceived privacy risk, perceived usefulness, trust, perceived overall risk, and perceived performance risk.

Another empirical study found that trust, security, and privacy are the main factors affecting adopting a digital wallet [25]. A survey conducted by Subaramaniam et al. [13] demonstrated that security risk problems limit the prospect of using the digital wallet in Malaysia. According to Li et al. [26], cloud computing, security, e-learning, and quality of service are four significant factors that affect customer satisfaction in e-banking services. In addition, another research suggested that trust and privacy have positively impacted behavioral intention to use mobile banking services [27]. Likewise, Putra and Sfenrianto [28] demonstrated that a good payment system's security factor and speed influenced customer satisfaction in the digital payment method. Oliveira et al. [29] suggested that the digital payment system's security and performance directly affect customer loyalty. The research also indicated that security has a significant impact on mobile banking adoption. Customers expect banks to improve their security mechanisms by providing transaction security and privacy protection, particularly over wireless networks [9]. The level of security provided by a third-party online payment provider influences customer satisfaction [41]. In addition, Tang et al. [42] found that service quality, perceived risk, perceived security, perceived simplicity of use, social influence, and compatibility all substantially impact on consumers' intention to utilize digital payment.

A variety of factors influence customer intent to use ewallets, including consumer perceptions of privacy, security.
Thus, the desire to use e-wallets is determined by the concern for transaction security and the protection of personal information given by users [43]. Furthermore, Qatawneh et al. [30] suggested that security and privacy statistically significantly impact the adoption of electronic payment system methods.

Previous researchers did not consider relevant security factors when assessing customer behavior but studied security as a general factor as shown in Appendix A. Besides, studies have shown that the security and privacy aspect of digital wallet systems when conducting transactions using digital wallet platforms is a primary concern for customers. The list of non-bank digital wallet issuers and the banks providing digital wallet services are shown in Appendix B and Appendix C, respectively.

The digital wallet services were developed for fast payment, school fee payments, handling expenses in fuel stations, global online shopping, NFC (Near Field Communication)-based transportation's payment, money transfer, bill payments, and others. Appendix B and Appendix C show 53 active digital wallet services, with 48 of them provided by Malaysian private and government fintech companies. The remaining five digital wallets are provided by international and local banks in Malaysia [44].

\section{FRAMEWORK AND HYPOTHESES}

Previous studies found that security substantially impacts consumer satisfaction in the digital wallet, but the studies examined security as an overall component. None of the research conducted identified the specific security factors in Malaysia's digital wallet. Thus, the current research proposed a six-factor security framework encompassing transaction speed, authentication, encryption mechanisms, software performance, privacy details, and information provided. Each factor was considered as a variable in this research. Fig. 1 represents the proposed framework of this study.

\section{A. Transaction Speed}

Transaction speed often refers to the rate at which data transfer happens from one record to another. The transfer speed is considered to be high if any transaction cannot be completed under a limited time period. An example of a real-life situation where transaction speed can be considered is the waiting time after the consumers have successfully paid for their online orders. The transaction speed of the payment application is a factor that may increase consumers' concerns [45]. The transaction speed is a characteristic that influences the development and satisfaction with any banking digital wallet technology. Numerous previous research found that transaction speed is a critical factor affecting consumer satisfaction with digital wallets [46]-[51]. Therefore, the following hypothesis is proposed:

- Hypothesis 1 (H1): There is a positive relationship between transaction speed and consumer satisfaction. 


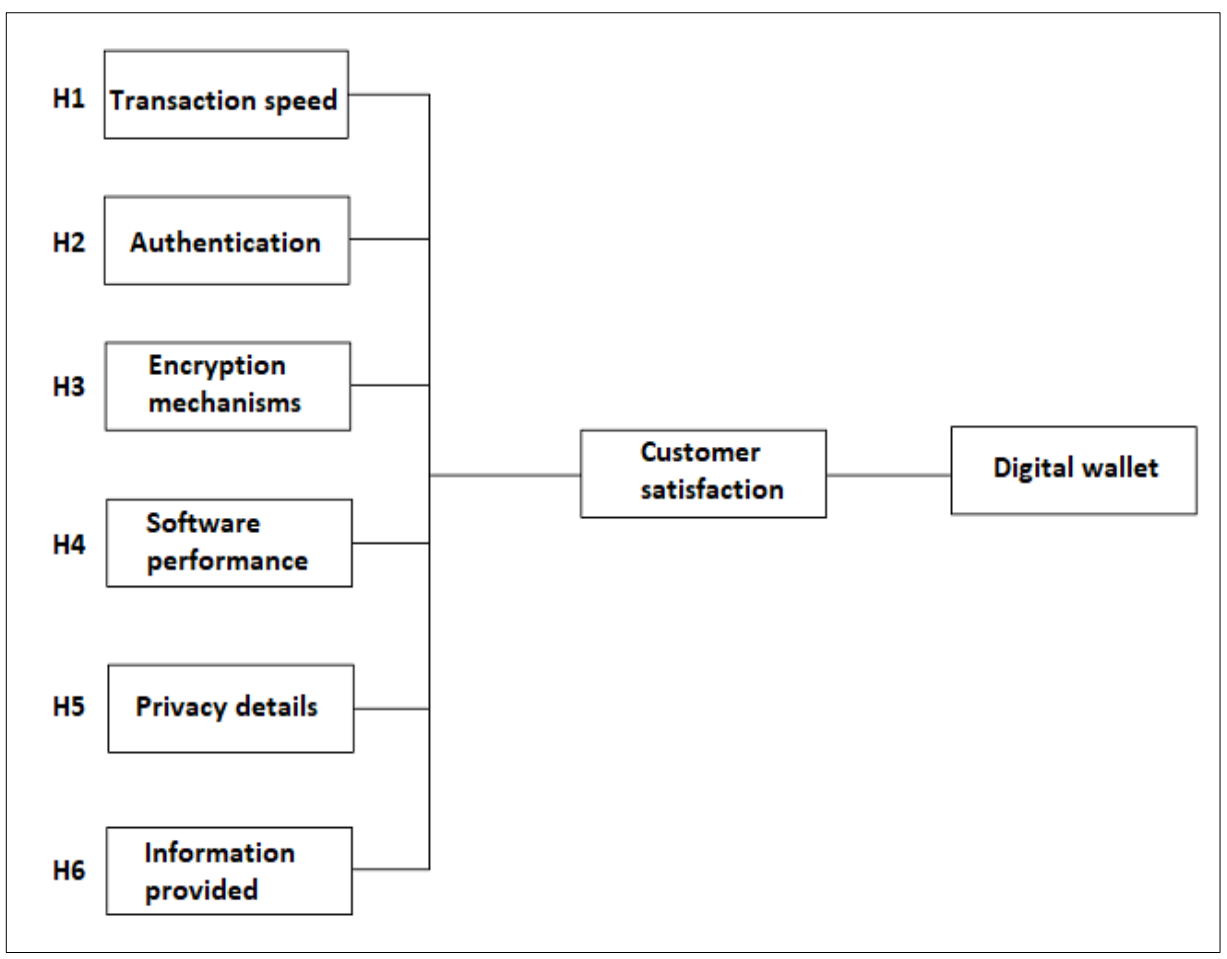

Fig. 1. The Proposed Framework for this Research.

\section{B. Authentication}

Authentication is a term that refers to the process of verifying a user's identification to guarantee that the activity being performed is being conducted by a trustworthy and real individual. It acts as a barrier to decrease the possibilities of identity theft. An exemplary situation of this would be the OTP code verification that consumers are required to do in order to complete their payment transactions. Authentication significantly impacts on consumer experience, which impacts their digital wallet adoption decision [52]-[54]. Because confidence is a significant influencing factor, digital wallet companies must guarantee that relevant aspects such as authentication are adequately regulated to build customer confidence [55]. Therefore, the following hypothesis is proposed:

- Hypothesis 2 (H2): There is a positive relationship between authentication and consumer satisfaction.

\section{Encryption Mechanisms}

Encryption mechanisms are often specific and unique steps and procedures done in turning order to encrypt data and ensure no third party or hackers can get the crucial information by encrypting the data into a gibberish form, which can only be decrypted using a unique key or mechanism corresponding to the encryption mechanism. Encryption mechanisms prevent hackers from breaking into a financial institution's server system. As a result, encryption mechanisms increase consumer confidence in conducting electronic payments [53], [56]. Therefore, the following hypothesis is proposed:

- Hypothesis 3 (H3): There is a positive relationship between encryption mechanisms and consumer satisfaction.

\section{Software Performance}

Software performance directs towards the overall performance of the software being used by consumers. In this case, performance acts as an indicator of how effectively the components and functions of the software meet their requirements. One of the most significant variables that directly influences acceptance intention for digital wallet is considered to be performance expectation [23], [57]-[59]. Incorrect functional usage situations and bugs in software may raise consumer worries. Therefore, the following hypothesis is proposed:

- Hypothesis 4 (H4): There is a positive relationship between software performance and consumer satisfaction.

\section{E. Privacy Details}

The information obtained from customers by digital services is referred to as privacy details in this context. Private information for registration purposes and authentication mechanisms are frequently included. Various previous studies have shown that customer satisfaction with digital wallets is significantly influenced by their ability to maintain their privacy [25], [60]-[65]. Therefore, the following hypothesis is proposed:

- Hypothesis 5 (H5): There is a positive relationship between privacy details and consumer satisfaction.

\section{F. Information Provided}

Because of the information provided by digital wallet services, customers of digital wallets may learn more about security. Customers may feel more confident about the security of the digital wallet system if they are informed of the security 
procedures. Similarly, if users of digital wallets are unaware of security procedures, they may not feel secure [66]. Digital payments service knowledge has an important, positive, and simultaneous impact on the customer's ongoing desire to use digital wallet services [67]. The security information given by digital wallet services may thus assist customers in learning more about security and increasing their confidence in the system. Therefore, the following hypothesis is proposed:

- Hypothesis 6 (H6): There is a positive relationship between information provided and consumer satisfaction.

\section{MEthodOLOGY}

This research adopted an empirical research method. A quantitative online survey was distributed to the students and professors at the National University of Malaysia who fulfilled the criteria of used any digital wallet platform, including mobile applications and web-based systems, at least once. Overall, 300 responses were received. The survey was divided into two sections. The respondents were requested to fill in their demographic data in the first section, whereas the respondents responded to the questionnaire on customer satisfaction in the second section. In the personal information section, respondents provided demographic data, including gender, age, occupation, and the frequency of digital wallet transactions.

A five-point Likert scale was used in the second section for respondents to specify their level of agreement on a statement. The degree of agreement is used for the study's assessment process. There were 18 questions in the second section divided into six sections, respectively. Three questions were asked for every element proposed in the framework. Factor analysis, reliability analysis, and multiple regression analysis were conducted with the recollected questionnaires. IBM's Statistical Package for Social Science (SPSS) version 22.0 software was used to assess the statistical significance. Table I shows the respondents' characteristics.

As shown in Table I, the majority of respondents use digital wallet platforms frequently, and it is famous among youngsters.

TABLE I. CHARACTERISTICS OF RESPONDENTS

\begin{tabular}{|l|l|l|}
\hline Indicator & Total cell & Accuracy (\%) \\
\hline \multirow{4}{*}{ Gender } & Male & $42 \%$ \\
\cline { 2 - 3 } & Female & $58 \%$ \\
\hline \multirow{4}{*}{ Age } & $18-25$ & $61.80 \%$ \\
\cline { 2 - 3 } & $26-35$ & $21.80 \%$ \\
\cline { 2 - 3 } & $36-45$ & $9.10 \%$ \\
\cline { 2 - 3 } Frequency of digital & $46-$ More & $7.30 \%$ \\
\hline \multirow{3}{*}{ wallet transactions } & Student & $89.90 \%$ \\
\cline { 2 - 3 } & Professor & $10.1 \&$ \\
\cline { 2 - 3 } & More than 3 times a week & $30.90 \%$ \\
\cline { 2 - 3 } & Once a week & $46.40 \%$ \\
\cline { 2 - 3 } & Less than once a week & $22.70 \%$ \\
\hline
\end{tabular}

\section{Results}

\section{A. Factor Analysis}

Factor analysis is commonly employed in multivariate data analysis to evaluate the underlying dimensions [68]-[70]. It is a data rebate technique that transforms many variables into few variables. The highly influential variables were removed from the dataset during the factor analysis. The dataset was replaced with less influential variables after extracting the highly influential variables. The Kaiser-Meyer-Olkin (KMO) sampling adequacy test and Bartlett's test of sphericity were conducted to examine the dataset's construction validity. Table II demonstrates the KMO and Bartlett's test.

According to Table II, the average value of KMO is .876 > 0.7, whereas the Bartlett test's significance level of sphericity is 0.00 , demonstrating that the collected data is normally distributed. The variables explained $87.6 \%$ of the variance from the total variance. Appendix D represents factor analysis. Each question posed for the six variables was used as a subvariable to analyze the factors. Each factor was assigned with an abbreviation. TS indicated transaction speed, AT stands for authentication, EM denotes encryption mechanism, SP represents software performance, PD signifies privacy details, IP implies information provided, and CS designates customer satisfaction. Appendix D demonstrates that factor loading variables are more significant than 0.6. The minimum factor loading value is 0.656 , and the maximum factor loading value is 0.965 .

\section{B. Reliability coefficient}

The reliability test was performed using the SPSS software to test the dataset's internal consistency and obtain the Cronbach alpha coefficients. The values of the Cronbach alpha coefficients are illustrated in Table III.

As shown in Table III, the Cronbach alpha coefficients' values for all the variables measured are above 0.700 . Cronbach alpha value of 0.700 or higher denotes an internally consistent dataset [71]-[73]. Therefore, the dataset received from the questionnaire survey satisfies the rule of thumb of validity.

TABLE II. KMO AND BARLETT's TEST

\begin{tabular}{|l|c|c|}
\hline \multicolumn{2}{|l|}{ KMO and Bartlett's Test } \\
\hline Kaiser-Meyer-Olkin Measure of Sampling Adequacy & & .876 \\
\hline Bartlett's Test of Sphericity & Sig. & 000 \\
\hline
\end{tabular}

TABLE III. RELIABILITY COEFFICIENT

\begin{tabular}{|l|l|l|}
\hline Variables & Number of Items & $\begin{array}{l}\text { Reliability Coefficient } \\
\text { (Cronbach Alpha) }\end{array}$ \\
\hline Transaction speed & 3 & .912 \\
\hline Authentication & 3 & .851 \\
\hline Encryption mechanisms & 3 & .828 \\
\hline Software performance & 3 & .942 \\
\hline Privacy details & 3 & .935 \\
\hline Information provided & 3 & .902 \\
\hline Customer satisfaction & 3 & .917 \\
\hline
\end{tabular}




\section{Regression Analysis}

Regression analysis is a practical way to analyze the variables and their connection [74]. The regression analysis is performed to identify the association between the dependent variable (customer satisfaction) and separate independent variables. The dataset's model summary is shown in Table IV.

As shown in Table IV, the $\mathrm{R}^{2}$ value is .723. The value represents a positive linear connection between customer satisfaction and other factors (independent variables) during the analysis. Table $\mathrm{V}$ shows the analysis of variance with a significant value less than 0.05 .

Therefore, it is found that the independent variables influence the dependent variable. The descriptions of the coefficients are exhibited in Table VI. The variable with the highest $\beta$-Value in Table VI is relatively most important independent variable.

The negative value of constant exhibited in Table VI defines that when transaction speed, authentication, encryption mechanisms, software performance, privacy details, and information provided values are 0 , the predicted value of customer satisfaction will be less than 0 . The regression coefficient calculates a unit change in the dependent variable when the $\beta$-value represents independent variable change. Based on the $\beta$-value shown in Table VI, the extent of the independent variable effect on the dependent variable can be identified. A high $\beta$-value corresponds to high effects. Table VII shows the results for collinearity when multiregression is applied. A Variance Inflation Factor (VIF) value greater than ten and a tolerance smaller than 0.2 implies a possible concern.

TABLE IV. MODEL SUMMARY

\begin{tabular}{|l|l|l|l|l|}
\hline Model & $\mathbf{R}$ & $\mathbf{R}^{\mathbf{2}}$ & Adjusted $\mathbf{R}^{\mathbf{2}}$ & Std. Error of the Estimation \\
\hline 1 & .850 & .723 & .717 & .41674 \\
\hline
\end{tabular}

TABLE V. ANALYSIS OF VARIANCE

\begin{tabular}{|l|l|l|l|l|l|}
\hline Model & Sum of Squares & Df & $\begin{array}{l}\text { Mean } \\
\text { Square }\end{array}$ & F & Sig. \\
\hline Regression & 132.793 & 6 & 22.132 & 127.434 & .000 \\
\hline Residual & 50.887 & 294 & .174 & & \\
\hline Total & 183.680 & 300 & & & \\
\hline
\end{tabular}

TABLE VI. ANALYSIS OF COEFFICIENTS

\begin{tabular}{|l|l|l|l|}
\hline \multirow{2}{*}{ Model } & \multicolumn{2}{|l|}{ Unstandardized Coefficients } & $\begin{array}{l}\text { Standardized } \\
\text { Coefficients }\end{array}$ \\
\cline { 2 - 4 } & $\boldsymbol{B}$ & Std. Error & $\boldsymbol{\beta}$-Value \\
\hline Constant & -0.770 & 0.181 & \\
\hline Transaction speed & 0.176 & 0.044 & 0.173 \\
\hline Authentication & 0.247 & 0.049 & 0.213 \\
\hline $\begin{array}{l}\text { Encryption } \\
\text { mechanisms }\end{array}$ & 0.112 & 0.039 & 0.111 \\
\hline Software performance & 0.215 & 0.045 & 0.189 \\
\hline Privacy details & 0.128 & 0.034 & 0.139 \\
\hline Information provided & 0.311 & 0.048 & 0.285 \\
\hline
\end{tabular}

TABLE VII. COLLINEARITY STATISTICS

\begin{tabular}{|l|l|l|l|l|}
\hline \multirow{2}{*}{ Model } & \multirow{2}{*}{ T } & \multirow{2}{*}{ Sig. } & \multicolumn{2}{|l|}{ Collinearity Statistics } \\
\cline { 3 - 5 } & & & Tolerance & VIF \\
\hline Constant & -4.248 & .000 & & \\
\hline Transaction speed & 4.024 & .000 & .513 & 1.948 \\
\hline Authentication & 5.040 & .000 & .530 & 1.887 \\
\hline Encryption mechanisms & 2.865 & .004 & .630 & 1.587 \\
\hline Software performance & 4.743 & .000 & .593 & 1.687 \\
\hline Privacy details & 3.794 & .000 & .701 & 1.427 \\
\hline Information provided & 6.529 & .000 & .498 & 2.008 \\
\hline
\end{tabular}

According to Table VII, The VIF values are below 10, whereas the tolerance values are above 0.2 for all the independent variables. Hence, multi-regression is appropriate for the model, and there is no collinearity problem. The value of statistical significance (p-value) less than 0.05 indicates a statistically relevant correlation between the dependent and independent variables. Table VII indicates that the level of statistical significance for the independent variables is below 0.05. Table VIII shows the relationship between each variable. The Pearson correlation values indicate that the variables have a strong and moderate association with one another.

TABLE VIII. PEARSON CORRELATION

\begin{tabular}{|c|c|c|c|c|c|c|c|}
\hline $\begin{array}{l}\text { Pearson } \\
\text { Correlation }\end{array}$ & $\mathbf{T P}^{\mathrm{a}}$ & Aut $^{\mathrm{b}}$ & $\mathbf{E M}^{\mathrm{c}}$ & $\mathbf{S P}^{\mathrm{d}}$ & $\mathbf{P D}^{\mathrm{e}}$ & $\mathbf{I P}^{\mathrm{f}}$ & $\mathbf{C S}^{\mathrm{g}}$ \\
\hline $\mathbf{T P}^{\mathrm{a}}$ & 1 & & & & & & \\
\hline Aut $^{\mathrm{b}}$ & .563 & 1 & & & & & \\
\hline $\mathbf{E M}^{\mathrm{c}}$ & .460 & .410 & 1 & & & & \\
\hline $\mathbf{S P}^{\mathrm{d}}$ & .524 & .508 & .484 & 1 & & & \\
\hline $\mathbf{P D}^{\mathrm{e}}$ & .459 & .407 & 417. & .431 & 1 & & \\
\hline $\mathbf{I P}^{\mathrm{f}}$ & .591 & .606 & .509 & .469 & .366 & 1 & \\
\hline $\mathrm{CS}^{\mathrm{g}}$ & .675 & .681 & .572 & .635 & .537 & .712 & 1 \\
\hline & & & & & $\begin{array}{c}\text { c. } \mathrm{EM} \\
{ }^{\text {d. }} \mathrm{SP} \\
{ }^{\text {f. }} \mathrm{IP} \\
{ }^{\text {g. }} \mathrm{CS}\end{array}$ & $\begin{array}{l}\text { = Tran } \\
\text { Au = A } \\
\text { incryptio } \\
\text { Software } \\
\text { e. } \mathrm{PD}=\mathrm{P} \\
\text { Informa } \\
\text { Custom }\end{array}$ & $\begin{array}{l}\text { ion Speed } \\
\text { entication } \\
\text { hechanism } \\
\text { rformance } \\
\text { acy details } \\
\text { provided } \\
\text { atisfaction }\end{array}$ \\
\hline
\end{tabular}

\section{Hypothesis Testing and Discussion}

Table IX demonstrates the hypotheses testing. The test was conducted based on the data collected.

The hypotheses testing reveals that the p-value for the relationship between transaction speed and customer satisfaction is equal to 0.000 , lesser than 0.05 . Hence, H1 is supported. Therefore, it can be asserted that transaction speed has a significant positive impact on customer satisfaction. The findings suggest that students and academicians are more likely to use digital wallet systems if the transaction speed is high. According to the survey results, faster transaction speed will mitigate the security fears among digital wallet users. Users believe that fast online money transaction boosts the digital ewallet platforms' security. 
TABLE IX. HYPOTHESIS TESTING

\begin{tabular}{|l|l|l|l|l|}
\hline Hypothesis & Factor & $\begin{array}{l}\boldsymbol{\beta} \text { - } \\
\text { Value }\end{array}$ & $\begin{array}{l}\text { p- } \\
\text { Value }\end{array}$ & Result \\
\hline H1 & Transaction speed & 0.173 & 0.000 & Supported \\
\hline H2 & Authentication & 0.213 & 0.000 & Supported \\
\hline H3 & $\begin{array}{l}\text { Encryption } \\
\text { mechanisms }\end{array}$ & 0.111 & 0.004 & Supported \\
\hline H4 & Software performance & 0.189 & 0.000 & Supported \\
\hline H5 & Privacy details & 0.139 & 0.000 & Supported \\
\hline H6 & Information provided & 0.285 & 0.000 & Supported \\
\hline
\end{tabular}

In addition, the p-value for the relationship between authentication and digital wallet customer satisfaction is less than 0.05 at 0.000 . Thus, the H2 is also supported, denoting that authentication has a significant positive impact on customer satisfaction. This finding shows that user's digital wallet account authentication process influences the digital wallet system's consumer satisfaction. Digital wallet users believe that user authentication keeps scammers at bay and enhances digital wallet security.

Furthermore, the p-value for the relationship between encryption mechanisms and customer satisfaction is 0.004 , which is less than 0.05. Therefore, H3 is supported. Thus, encryption mechanisms are found to exert a significant positive impact on customer satisfaction. The survey participants are concerned about accepting or denying digital wallet services with the encryption mechanisms. Similarly, the participants believe that a strong encryption mechanism will avoid abuse or hacking user information while using a digital wallet.

The $\mathrm{p}$-value of software performance is 0.000 , which is less than 0.05. Thus, the H4 is supported, indicating that software performance significantly impacts customer satisfaction. The findings confirm that digital wallet users are aware of software performance when using digital wallet platforms. Moreover, digital wallet users suspect that software with vulnerabilities increases the risk of digital wallet fraud.

Additionally, the p-value for the relationship between privacy details and customer satisfaction is 0.000 , less than 0.05 . Hence, $\mathrm{H} 5$ is also supported, concluding that privacy details significantly impact customer satisfaction. It suggests that private data collected from digital wallet users concern them. The digital wallet users opined that security vulnerabilities could be triggered by information collected through digital wallet platforms.

According to Table IX, H6 is also supported because the information provided has a p-value of 0.000 , less than 0.05 . Hence, the information provided has a significant positive impact on customer satisfaction. The finding shows that information provided by the digital wallet systems allows users of digital wallets to learn more about security. Providing additional security information increases the online payment systems' credibility. Furthermore, consumers will feel reassured about the digital wallet system's security when they are aware of software performance. Therefore, the study concluded that the proposed security factors significantly influence digital wallet consumer satisfaction based on the hypotheses tested.
From Table IX, among the studied factors, the information provided has the highest $\beta$-value (.285), indicating that the information provided to digital wallet users most significantly influence consumer satisfaction, followed by authentication (.213), software performance (.189), transaction speed (.173), privacy details (.139), and finally, encryption mechanisms (.111). From the analysis, the six influencing factors on customer satisfaction are arranged in ascending order according to their significant influences: Information Provided $>$ Authentication $>$ Software Performance $>$ Transaction Speed $>$ Privacy Details $>$ Encryption Mechanisms.

\section{LiMITATION OF THE STUDY}

Security was only covered as a general factor in previous studies. This study is the first research undertaken to identify the specific security factors for the digital wallet in Malaysia. However, this research was carried out based on responses from students and professors from the National University of Malaysia who may have better security factors awareness. Further research is required in this area of study. Security variables are complicated theoretical subjects for comprehension and research. An in-depth study of various populations is required to assess the factors suggested in this research. In addition, prospective researchers should also consider different security variables.

\section{CONCLUSION}

This research has proposed a six-factor security framework that influences consumer satisfaction in Malaysia's digital wallet. Conclusively, all the proposed factors in the research have a significant positive influence on consumer satisfaction. Based on the analysis, the information provided most significantly influences customer satisfaction in digital wallets, followed by authentication, software performance, transaction speed, privacy details, and encryption mechanisms. Hence, improvised information security management principles are essential for the advancement of the digital wallet industry.

Digital wallets have gained popularity in recent times for providing cashless and comfortable daily payments or transactions. Although digital wallets deal with payments or transactions, research on considering and deducing security factors when developing digital wallet payment systems is limited. The progress of the digital wallet industry may impede without a thorough understanding of security factors. This research contributes to understanding the specific security factors necessary for financial technology companies. This study identifies new security factors that influence consumer satisfaction in digital wallet payment methods. The factors have not been analyzed in previous research. Therefore, this study contributes critically to the theoretical literature in digital wallet payments.

Consumer satisfaction is a crucial factor in the future for the booming digital wallet industry. Digital wallet security must be advanced to deal with emerging hackers and frauds. The outcome of this research can assist digital wallet providers in reinforcing the security of the system and focusing on crucial security factors to enhance customer satisfaction towards digital wallets. Moreover, this study can assist future 
researchers planning to study this field by considering the variables proposed in this study.

\section{ACKNOWLEDGMENT}

This work was supported by the Ministry of Higher Education Malaysia (FRGS/1/2018/ICT01/UKM/02/5) and Universiti Kebangsaan Malaysia (GUP-2020-060).

\section{REFERENCES}

[1] S. L. Miruna, "A Study on Customer Satisfaction Towards E - wallets in Tirunelveli City,” Ijciras, vol. 2, no. 1, pp. 3-6, 2019.

[2] M. Yang, A. Al Mamun, M. Mohiuddin, N. C. Nawi, and N. R. Zainol, "Cashless transactions: A study on intention and adoption of e-wallets," Sustain., vol. 13, no. 2, pp. 1-18, 2021, doi: 10.3390/su13020831.

[3] H. H. Bin Kadar, S. S. B. Sameon, M. B. M. Din, and P. 'Amirah B. A. Rafee, "Malaysia Towards Cashless Society,” Lect. Notes Electr. Eng., vol. 565, pp. 34-42, 2019, doi: 10.1007/978-3-030-20717-5_5.

[4] Bernama, "Malaysia moving towards cashless society," Free Malaysia Today. 2017; Available from: https://www.freemalaysiatoday.com/category/nation/2017/12/08/malaysi a-moving-towards-a-cashless-society-say-bank-negara/ (accessed on 27 October 2021).

[5] S. M. H. Mahmud, M. A. Kabir, O. A. M. Salem, and K. N. G. Fernand, "The comparative analysis of online shopping information platform's security based on customer satisfaction," Proc. 2016 5th Int. Conf. Comput. Sci. Netw. Technol. ICCSNT 2016, no. 2012, pp. 157-161, 2017, doi: 10.1109/ICCSNT.2016.8070139.

[6] D. H. Shin, "Towards an understanding of the consumer acceptance of mobile wallet," Comput. Human Behav., vol. 25, no. 6, pp. 1343-1354, 2009, doi: 10.1016/j.chb.2009.06.001.

[7] M. J. López-Miguens and E. G. Vázquez, "An integral model of eloyalty from the consumer's perspective,” Comput. Human Behav., vol. 72, pp. 397-411, 2017, doi: 10.1016/j.chb.2017.02.003.

[8] F. Nizam, H. J. Hwang, and N. Valaei, "Measuring the effectiveness of E-wallet in Malaysia," vol. 786. Springer International Publishing, 2019.

[9] S. Singh and R. K. Srivastava, "Predicting the intention to use mobile banking in India,” Int. J. Bank Mark., vol. 36, no. 2, pp. 357-378, 2018, doi: 10.1108/IJBM-12-2016-0186.

[10] M. A. Hassan, Z. Shukur, M. K. Hasan, and A. S. Al-Khaleefa, "A Review on Electronic Payments Security,” Symmetry (Basel)., vol. 12, no. 8, p. 1344, Aug. 2020, doi: 10.3390/sym12081344.

[11] K. L. Y. Ming, M. Jais, C. C. Wen, and N. S. Zaidi, "Factor Affecting Adoption of E-Wallet in Sarawak," Int. J. Acad. Res. Accounting, Financ. Manag. Sci., vol. 10, no. 2, pp. 244-256, 2020, doi: 10.6007/IJARAFMS/v10-i2/7446.

[12] S. Luo, Y. Hu, and Y. Zhou, "Factors attracting Chinese Generation Y in the smartphone application marketplace," Front. Comput. Sci., vol. 11, no. 2, pp. 290-306, Apr. 2017, doi: 10.1007/s11704-016-5022-8.

[13] K. Subaramaniam, R. Kolandaisamy, A. Bin Jalil, and I. Kolandaisamy, "The impact of E-Wallets for current generation," J. Adv. Res. Dyn. Control Syst., vol. 12, no. 1 Special Issue, pp. 751-759, 2020, doi: 10.5373/JARDCS/V12SP1/20201126.

[14] N. Kumari and J. Khanna, "Cashless Payment: A Behaviourial Change To Economic Growth,” Qual. Quant. Res. Rev., vol. 2, no. 2, 2017, doi: 10.18535/ijsre/v5i07.03.

[15] Digital News Asia, "Almost 50\% of Malaysian consumers distrust of online payment security," Digit. News Asia 2018; Available from: https://www.digitalnewsasia.com/digital-economy/almost-50-malaysianconsumers-distrust-online-paymentsecurity?_cf_chl_jschl_tk_=pmd_1f36948d55bb8f989a3598e243b047 8e129e9d4c-1627744177-0-gqNtZGzNAjijcnBszQi6 (accessed on 31 July 2021).

[16] M. Wolfinbarger and M. C. Gilly, "eTailQ: Dimensionalizing, measuring and predicting etail quality," J. Retail., vol. 79, no. 3, pp. 183-198, 2003, doi: 10.1016/S0022-4359(03)00034-4.

[17] M. Al-Okaily, A. Lutfi, A. Alsaad, A. Taamneh, and A. Alsyouf, "The Determinants of Digital Payment Systems’ Acceptance under Cultural
Orientation Differences: The Case of Uncertainty Avoidance,” Technol. Soc., vol. 63, no. September, 2020, doi: 10.1016/j.techsoc.2020.101367.

[18] C. Ranganathan and S. Jha, "Examining online purchase intentions in B2C E-commerce: Testing an integrated model,” Inf. Resour. Manag. J., vol. 20, no. 4, pp. 48-64, Oct. 2007, doi: 10.4018/irmj.2007100104.

[19] N. I. Ali, S. Samsuri, M. Sadry, I. A. Brohi, and A. Shah, "Online shopping satisfaction in Malaysia: A framework for security, trust and cybercrime," Proc. - 6th Int. Conf. Inf. Commun. Technol. Muslim World, ICT4M 2016, no. November, pp. 194-198, 2017, doi: 10.1109/ICT4M.2016.43.

[20] Schaupp, L.C.; Bélanger, F. "A conjoint analysis of online consumer satisfaction," J. of Electr. Commer. Res. 2005; Vol. 6.

[21] W. Karim, A. Haque, M. A. Ulfy, A. Hossain, and Z. Anis, "Factors Influencing the Use of E-wallet as a Payment Method among Malaysian Young Adults,” JIBM, J. Int. Bus. Manag., doi: 10.37227/jibm-2020-221.

[22] M. Barry and M. T. Jan, "Factors Influencing the Use of M-Commerce: An Extended Technology Acceptance Model Perspective,” Int. J. Econ. Manag. Account., vol. 26, no. 1, pp. 157-183, 2018.

[23] N. N. M. Razif, M. Misiran, H. Sapiri, "Perceived risk for acceptance of E-wallet platform in Malaysia among youth: Sem approach,” Manag. Res. J., vol. 9, pp. 1-24, 2020.

[24] H. R. Peikari, "The influence of security statement, technical protection, and privacy on satisfaction and loyalty; a structural equation modeling," Commun. Comput. Inf. Sci., vol. 92 CCIS, no. October, pp. 223-231, 2010, doi: 10.1007/978-3-642-15717-2_24.

[25] E. D. Matemba and G. Li, "Consumers' willingness to adopt and use WeChat wallet: An empirical study in South Africa," Technol. Soc., vol. 53, pp. 55-68, 2018, doi: 10.1016/j.techsoc.2017.12.001.

[26] F. Li, H. Lu, M. Hou, K. Cui, and M. Darbandi, "Customer satisfaction with bank services: The role of cloud services, security, e-learning and service quality,” Technol. Soc., vol. 64, no. July 2020, p. 101487, 2021, doi: 10.1016/j.techsoc.2020.101487.

[27] F. O. Bankole and O. O. Bankole, "The effects of cultural dimension on ICT innovation: Empirical analysis of mobile phone services," Telemat. Informatics, vol. 34, no. 2, pp. 490-505, 2017, doi: 10.1016/j.tele.2016.08.004.

[28] H. R. Putra and Sfenrianto, "Analysis of customer satisfaction factors on e-commerce payment system methods in Indonesia," Int. J. Adv. Comput. Sci. Appl., vol. 11, no. 4, pp. 471-480, 2020, doi: 10.14569/IJACSA.2020.0110463.

[29] T. Oliveira, M. Thomas, G. Baptista, and F. Campos, "Mobile payment: Understanding the determinants of customer adoption and intention to recommend the technology," Comput. Human Behav., vol. 61, no. 2016, pp. 404-414, 2016, doi: 10.1016/j.chb.2016.03.030.

[30] A. M. Qatawneh, F. M. Aldhmour, and S. M. Alfugara, "The Adoption of Electronic Payment System (EPS) in Jordan: Case Study of Orange Telecommunication Company,” J. Bus. Manag., vol. 6, no. 22, pp. 2222-2847, 2015.

[31] B. Liu, Y. Li, B. Zeng, and C. Lei, "An efficient trust negotiation strategy towards the resource-limited mobile commerce environment," Front. Comput. Sci., vol. 10, no. 3, pp. 543-558, Jun. 2016, doi: 10.1007/s11704-015-4559-2.

[32] K. B. Ooi and G. W. H. Tan, "Mobile technology acceptance model: An investigation using mobile users to explore smartphone credit card," Expert Syst. Appl., Oct. 2016, vol. 59, pp. 33-46, doi: 10.1016/j.eswa.2016.04.015.

[33] V. L. Johnson, A. Kiser, R. Washington, and R. Torres, "Limitations to the rapid adoption of M-payment services: Understanding the impact of privacy risk on M-Payment services," Comput. Human Behav., vol. 79, pp. 111-122, 2018, doi: 10.1016/j.chb.2017.10.035.

[34] K. Chan, C. Leong, B. Lim, and C. Yiong, "Sharing Economy through E-Wallet: Understanding the Determinants of User Intention in Malaysia,” J. Mark. Adv. Prat., vol. 2, no. 2, pp. 1-18, 2020.

[35] M. S. M. Ariff, M. Sylvester, N. Zakuan, K. Ismail, and K. M. Ali, "Consumer perceived risk, attitude and online shopping behaviour; Empirical evidence from Malaysia,” IOP Conf. Ser. Mater. Sci. and Eng., June 2014, vol. 58, no. 1, p. 012007, doi: 10.1088/1757899X/58/1/012007. 
[36] L. Yu, Z. Chen, P. Yao, and H. Liu, "A study on the factors influencing users' online knowledge paying-behavior based on the utaut model," J. Theor. Appl. Electron. Commer. Res., vol. 16, no. 5, pp. 1768-1790, 2021, doi: 10.3390/jtaer16050099.

[37] M. F. Wei, Y. H. Luh, Y. H. Huang, and Y. C. Chang, "Young generation's mobile payment adoption behavior: Analysis based on an extended utaut model,” J. Theor. Appl. Electron. Commer. Res., vol. 16, no. 4, pp. 1-20, 2021, doi: 10.3390/jtaer16040037.

[38] Saylikhanov, S. "Factors Influencing Customer Satisfaction Towards Lazada Online Shopping in Malaysia," Available online: http://studentrepo.iium.edu.my/handle/123456789/3184 (accessed on 31 July 2021).

[39] S. S. Alam, M. H. Ali, N. A. Omar, and W. M. H. W. Hussain, "Customer satisfaction in online shopping in growing markets: An empirical study,” Int. J. Asian Bus. Inf. Manag., vol. 11, no. 1, pp. 7891, 2020, doi: 10.4018/IJABIM.2020010105.

[40] J. Kasuma, A. Kanyan, M. Khairol, N. Sa'ait, and G. Panit, "Factors Influencing Customers Intention for Online Shopping,” Int. J. of Modern Trends in Bus. Res. 2020, 3, 31-41.

[41] Y. Choi and L. Sun, "Reuse intention of third-party online payments: A focus on the sustainable factors of alipay," Sustain., vol. 8, no. 2, pp. 115, 2016, doi: 10.3390/su8020147.

[42] Y. M. Tang, K. Y. Chau, L. Hong, Y. K. Ip, and W. Yan, "Financial innovation in digital payment with wechat towards electronic business success,” J. Theor. Appl. Electron. Commer. Res., vol. 16, no. 5, pp. 1844-1861, 2021, doi: 10.3390/jtaer16050103.

[43] V. Soodan and A. Rana, "Modeling customers' intention to use e-wallet in a developing nation: Extending UTAUT2 with security, privacy and savings,” J. Electron. Commer. Organ., vol. 18, no. 1, pp. 89-114, 2020, doi: 10.4018/JECO.2020010105.

[44] Non-bank E-money issuers. Bank Negara Malaysia. Available from: https://www.bnm.gov.my/non-bank-e-money-issuers (accessed on 31 July 2021).

[45] R. Anjali and A. Suresh, "A study on customer satisfaction of bharat interface for money (BHIM), ’ Int. J. Innov. Technol. Explor. Eng., vol. 8, no. 6, pp. 266-273, 2019.

[46] A. S. Yang, "Exploring Adoption difficulties in mobile banking services,” Can. J. Adm. Sci., vol. 26, no. 2, pp. 136-149, 2009, doi: 10.1002/cjas.102.

[47] Ahmadinejad, B. "The impact of customer satisfaction on word of mouth marketing (Case study: Bamilo online store)," SCIREA J. Manag. 2019.

[48] G. M. Ling, Y. S. Fern, L. K. Boon, and T. S. Huat, "Understanding Customer Satisfaction of Internet Banking: A Case Study In Malacca," Procedia Econ. Financ., vol. 37, no. 16, pp. 80-85, 2016, doi: 10.1016/s2212-5671(16)30096-x.

[49] A. M. Khalaf Ahmad and H. Ali Al-Zu'bi, "E-banking Functionality and Outcomes of Customer Satisfaction: An Empirical Investigation,” Int. J. Mark. Stud., vol. 3, no. 1, pp. 50-65, 2011, doi: 10.5539/ijms.v3n1p50.

[50] M. Jannat and I. Ahmed, "Factors Influencing Customer Satisfaction of Mobile Banking Services : A Study on Second - Generation Banks," Eur. J. Bus. Manag., vol. 7, no. 26, pp. 88-97, 2015.

[51] N. Jahan, M. J. Ali, and A. Al Asheq, "Examining the key determinants of customer satisfaction internet banking services in Bangladesh," Acad. Strateg. Manag. J., vol. 19, no. 1, pp. 1-6, 2020.

[52] Cheah, J.S.; Isa, S.M.; Yang, S. "The Impact of Perceived Usefulness, Perceived Value, and Perceived Security on Mobile Payment App Loyalty through Satisfaction: User Interface as Moderator," Proc. The 41th Nat. and Int. Conf. Glob. Goals, Loc. Act. Look. Back and Mov. For. 2021, 1, 14.

[53] N. N. Duy Phuong, L. T. Luan, V. Van Dong, and N. Le Nhat Khanh, "Examining customers' continuance intentions towards e-wallet usage: The emergence of mobile payment acceptance in Vietnam," J. Asian Financ. Econ. Bus., vol. 7, no. 9, pp. 505-516, 2020, doi: 10.13106/JAFEB.2020.VOL7.NO9.505.

[54] C. S. Weir, G. Douglas, M. Carruthers, and M. Jack, "User perceptions of security, convenience and usability for ebanking authentication tokens,” Comput. Secur., vol. 28, no. 1-2, pp. 47-62, 2009, doi: 10.1016/j.cose.2008.09.008.

[55] Bhatt, V. "Factors affecting the consumer's adoption of $\mathrm{E}$-wallets in India : An empirical study," SAL. Inst. of Man. 2020, 9, 6.

[56] S. Phophalia, G. Goswami, M. Prasad, M. Arora, and B. Graph, “A Study on Impact on Customer Satisfaction for E-Wallet Using Path Analysis model,” J. Bank. Insur. Law, no. Iccm, 2018.

[57] X. Luo, H. Li, J. Zhang, and J. P. Shim, "Examining multi-dimensional trust and multi-faceted risk in initial acceptance of emerging technologies: An empirical study of mobile banking services,” Decis. Support Syst., vol. 49, no. 2, pp. 222-234, 2010, doi: 10.1016/j.dss.2010.02.008.

[58] G. Baptista and T. Oliveira, "Understanding mobile banking: The unified theory of acceptance and use of technology combined with cultural moderators," Computers in Human Behavior, vol. 50. pp. 418430, 2015, doi: 10.1016/j.chb.2015.04.024.

[59] T. Zhou, Y. Lu, and B. Wang, "Integrating TTF and UTAUT to explain mobile banking user adoption,” Comput. Human Behav., vol. 26, no. 4, pp. 760-767, 2010, doi: 10.1016/j.chb.2010.01.013.

[60] H. Alnaaji and A. Qusef, "A Conceptual Framework for Representing Business Functions and Their Role in the Quality of E-Banking Services,” 2021 Int. Conf. Inf. Technol. ICIT 2021 - Proc., pp. 627-633, Jul. 2021, doi: 10.1109/ICIT52682.2021.9491726.

[61] M. F. Putri, B. Purwandari, and A. N. Hidayanto, "What do affect customers to use mobile payment continually? A systematic literature review," 2020 5th Int. Conf. Informatics Comput. ICIC 2020, Nov. 2020, doi: 10.1109/ICIC50835.2020.9288590.

[62] C. Ayu, K. Larasati, and R. A. Salim, "Analysis of Factors Influencing Continuance Intention of E-wallet Use : A Case Study of LinkAja," Irjaes, vol. 6, no. 2, pp. 27-33, 2021.

[63] C. Mombeuil, "An exploratory investigation of factors affecting and best predicting the renewed adoption of mobile wallets," J. Retail. Consum. Serv., vol. 55, no. April, p. 102127, 2020, doi: 10.1016/j.jretconser.2020.102127.

[64] M. Darmiasih and P. Y. Setiawan, "Continuance usage intention and its antecedents on using OVO e-wallet application in Denpasar," Int. Res. J. Manag. IT Soc. Sci., vol. 8, no. 1, pp. 35-46, 2020, doi: 10.21744/irjmis.v8n1.1104.

[65] P. Sarika and S. Vasantha, "Review on Influence of Trust on Mobile Wallet Adoption and its Effect on Users' Satisfaction,” Int. J. Manag., vol. 8, no. 1731, pp. 1731-1744, 2018.

[66] Akhila Pai H. Study on consumer perception towards digital wallets. Int. J. Res. Anal. Rev. 2018, 5, 385-391.

[67] Lim, S.H.; Kim, D.J.; Hur, Y.; Park, K. "An Empirical Study of the Impacts of Perceived Security and Knowledge on Continuous Intention to Use Mobile Fintech Payment Services," Int. J. of Human Comput. Inter. 2018, 35, 886-898, doi:10.1080/10447318.2018.1507132.

[68] N. Ghazali and M. S. Nordin, "Measuring meaningful learning experience: Confirmatory factor analysis,” Int. J. Innov. Creat. Chang., vol. 9, no. 12, pp. 283-296, 2019.

[69] S. McQuitty, "The Purposes of Multivariate Data Analysis Methods: an Applied Commentary,” J. African Bus., vol. 19, no. 1, pp. 124-142, 2018, doi: 10.1080/15228916.2017.1374816.

[70] Bornmann, L.; Haunschild, R. Do altmetrics correlate with the quality of papers? A large-scale empirical study based on F1000 prime data. PloS one 2018, 13, e0197133, doi:10.1371/journal.pone.0197133.

[71] Nunnally JC. "Psychometric theory 3E," Tata McGraw-hill education 1994.

[72] Van Griethuijsen, R.A.L.F., van Eijck, M.W., Haste, H. et al. "Global Patterns in Students' Views of Science and Interest in Science," Res Sci Educ., 2015, 45, 581-603, doi:10.1007/s11165-014-9438-6.

[73] K. S. Taber, “The Use of Cronbach's Alpha When Developing and Reporting Research Instruments in Science Education,” Res. Sci. Educ., vol. 48, no. 6, pp. 1273-1296, 2018, doi: 10.1007/s11165-016-9602-2.

[74] Fang, S. Empirical Study of Influential Elements of University Students' E-satisfaction. Int. J. of Bus. and Soc. Sci. 2014, 5, 6. 
APPENDIX A

\begin{tabular}{|c|c|c|c|}
\hline Ref & Objective & Finding & Limitation \\
\hline [8] & $\begin{array}{l}\text { Identify the significant factors affecting the } \\
\text { purchasing intention of customers using E- } \\
\text { wallet in Malaysia. }\end{array}$ & $\begin{array}{l}\text { Convenience, cost-savings, and security were identified to } \\
\text { impact customer purchasing behavior using E-wallet. }\end{array}$ & $\begin{array}{l}\text { Security factors were not considered as } \\
\text { variables. }\end{array}$ \\
\hline [9] & $\begin{array}{l}\text { Analyze the variables affecting the customer's } \\
\text { decision to use mobile banking in India. }\end{array}$ & $\begin{array}{l}\text { Perceived ease of use, usability, social effects, security, } \\
\text { and perceived cost affect the decision of customers to use } \\
\text { mobile banking. }\end{array}$ & $\begin{array}{l}\text { The influence of security variables was } \\
\text { not addressed in this study. }\end{array}$ \\
\hline [11] & $\begin{array}{l}\text { Examine the variables that impact the } \\
\text { acceptance of E-wallet services in Sarawak, } \\
\text { Malaysia. }\end{array}$ & $\begin{array}{l}\text { The acceptance of e-wallet services is influenced by } \\
\text { perceived risk, perceived usefulness, and perceived ease. }\end{array}$ & $\begin{array}{l}\text { Security variables were not considered to } \\
\text { identify the perceived risk factors. }\end{array}$ \\
\hline [13] & $\begin{array}{l}\text { Assess the positive and negative effects of e- } \\
\text { wallet on Malaysian users. }\end{array}$ & $\begin{array}{l}\text { The limitations of using the digital wallet in Malaysia are } \\
\text { technological challenges and security risks. }\end{array}$ & $\begin{array}{l}\text { The analysis did not classify digital } \\
\text { wallet security risks but instead } \\
\text { considered security as a general aspect. }\end{array}$ \\
\hline [17] & $\begin{array}{l}\text { Explain and recognize the nature of adopting } \\
\text { the digital payment system in Jordan on the } \\
\text { framework of the UTAUT2 model. }\end{array}$ & $\begin{array}{l}\text { Performance expectations, social effect, price value, } \\
\text { security, and privacy were important digital payment } \\
\text { system acceptance indicators. }\end{array}$ & $\begin{array}{l}\text { Security factors were not considered as } \\
\text { variables. }\end{array}$ \\
\hline [18] & $\begin{array}{l}\text { Identify the relative primary factors that } \\
\text { impact online purchase intentions. }\end{array}$ & $\begin{array}{l}\text { Privacy, security, and delivery have a significant positive } \\
\text { impact on customer satisfaction when it comes to online } \\
\text { purchase intention. }\end{array}$ & $\begin{array}{l}\text { The study does not identify the specific } \\
\text { security factors for digital wallet systems. }\end{array}$ \\
\hline [19] & $\begin{array}{l}\text { Proposed a framework of the security factors } \\
\text { in online shopping. }\end{array}$ & $\begin{array}{l}\text { This framework has five security factors: financial } \\
\text { security, privacy, system security, cybercrime, trust, and } \\
\text { customer satisfaction. }\end{array}$ & $\begin{array}{l}\text { The study does not identify the specific } \\
\text { security factors for digital wallet system. }\end{array}$ \\
\hline [20] & $\begin{array}{l}\text { An analysis to determine the attributes that } \\
\text { impact customer satisfaction in online } \\
\text { shopping. }\end{array}$ & $\begin{array}{l}\text { Privacy, merchandising, convenience, trust, delivery, } \\
\text { usability, product customization, product quality, and } \\
\text { security are the important attributes to the consumer for } \\
\text { online satisfaction. }\end{array}$ & $\begin{array}{l}\text { Specific security factors were not } \\
\text { considered as variables. }\end{array}$ \\
\hline [21] & $\begin{array}{l}\text { Identify the primary factors that contribute to } \\
\text { the acceptance of electronic payment systems. }\end{array}$ & $\begin{array}{l}\text { Compatibility, the perceived security of technology, } \\
\text { performance expectations, creativity, and social impact } \\
\text { have important beneficial and detrimental effects on the } \\
\text { acceptance and recommendation of electronic payment } \\
\text { systems. }\end{array}$ & $\begin{array}{l}\text { The analysis did not consider security } \\
\text { factors but rather addressed security as a } \\
\text { general factor to assess consumer } \\
\text { behavior. }\end{array}$ \\
\hline [22] & $\begin{array}{l}\text { Investigate the variables that have a } \\
\text { significant impact on the adoption of Jordan's } \\
\text { electronic payment systems. }\end{array}$ & $\begin{array}{l}\text { Security and privacy have a statistically significant impact } \\
\text { on the adoption of electronic payment system methods. }\end{array}$ & $\begin{array}{l}\text { This research does not identify particular } \\
\text { security factors to assess the behavior of } \\
\text { consumers to prevent ambiguity. }\end{array}$ \\
\hline [23] & $\begin{array}{l}\text { Examine the driving factors over the use of e- } \\
\text { wallet as a payment method by Malaysian } \\
\text { young adults. }\end{array}$ & $\begin{array}{l}\text { Perceived usefulness, perceived ease of use and privacy } \\
\text { and security have a positive and vital association with the } \\
\text { e-wallet behavioral intention. }\end{array}$ & $\begin{array}{l}\text { Security was considered as a general } \\
\text { factor; specific security variables were } \\
\text { not studied. }\end{array}$ \\
\hline [24] & $\begin{array}{l}\text { Analyze the factors influencing m-commerce } \\
\text { use in Malaysia. }\end{array}$ & $\begin{array}{l}\text { Perceived usefulness, perceived satisfaction, security, and } \\
\text { privacy have a significant positive impact on the } \\
\text { behavioral intention of m-commerce use in Malaysia. }\end{array}$ & $\begin{array}{l}\text { The study does not consider specific } \\
\text { security factors as variables. Security was } \\
\text { considered a general factor. }\end{array}$ \\
\hline [25] & $\begin{array}{l}\text { Analyze the perceived risk that represents the } \\
\text { ambiguity of adverse effects over e-wallets in } \\
\text { Malaysia on consumer emotions. }\end{array}$ & $\begin{array}{l}\text { The perceived risk of privacy, perceived usefulness, trust, } \\
\text { perceived general risk, and perceived risk of performance } \\
\text { are directly linked to the acceptance of the e-wallet } \\
\text { platform. }\end{array}$ & $\begin{array}{l}\text { The study does not specify the specific } \\
\text { security factors for the digital wallet } \\
\text { system. }\end{array}$ \\
\hline [26] & $\begin{array}{l}\text { Investigate the influence of security } \\
\text { statements, technical protection, trust, and } \\
\text { privacy on customer satisfaction, in the world } \\
\text { of e-commerce. }\end{array}$ & $\begin{array}{l}\text { Security statements and technical protection significantly } \\
\text { impact customer loyalty in the e-commerce industry, and } \\
\text { the study found no substantial effect on privacy. }\end{array}$ & $\begin{array}{l}\text { The study considered security statements } \\
\text { as a variable and did not study specific } \\
\text { security factors. }\end{array}$ \\
\hline [27] & $\begin{array}{l}\text { Predict the extent of adoption of the People- } \\
\text { to-People (P2P) services of the WeChat wallet } \\
\text { in South Africa. }\end{array}$ & $\begin{array}{l}\text { Trust, security, and privacy impact the decisions of South } \\
\text { Africans to accept the WeChat wallet. }\end{array}$ & $\begin{array}{l}\text { The research was based on WeChat } \\
\text { wallet mainly, did not include other e- } \\
\text { wallet services, and did not analyse } \\
\text { security factors. }\end{array}$ \\
\hline [28] & $\begin{array}{l}\text { Examine the variables impacting consumer } \\
\text { satisfaction with e-banking systems. }\end{array}$ & $\begin{array}{l}\text { Cloud computing, security, e-learning, and quality of } \\
\text { service are factors that can improve customer loyalty with } \\
\text { e-banking. }\end{array}$ & $\begin{array}{l}\text { The study did not specify digital wallet } \\
\text { security variables. }\end{array}$ \\
\hline [29] & $\begin{array}{l}\text { Examine the influence of socio-cultural } \\
\text { factors on ICT innovation, emphasizing } \\
\text { mobile banking services in South Africa. }\end{array}$ & $\begin{array}{l}\text { Trust and privacy have a significant impact on the } \\
\text { behavior intention of using mobile banking services. }\end{array}$ & $\begin{array}{l}\text { The analysis does not identify the } \\
\text { security factors that affect consumer } \\
\text { behavior. }\end{array}$ \\
\hline [30] & $\begin{array}{l}\text { Identify the variables that affect consumer } \\
\text { satisfaction on the systems of electronic } \\
\text { payment in Indonesia. }\end{array}$ & $\begin{array}{l}\text { Customer loyalty has a significant influence on service } \\
\text { effectiveness, benefits provided, the security of } \\
\text { transactions, speed, active usage, benefits received, and } \\
\text { convenience of transactions. }\end{array}$ & $\begin{array}{l}\text { The analysis did not classify digital } \\
\text { wallet security risks but rather considered } \\
\text { the security of transactions as a general } \\
\text { aspect. }\end{array}$ \\
\hline [35] & $\begin{array}{l}\text { Identify the variables that impact consumer } \\
\text { perceived risk and their attitude toward online } \\
\text { shopping in Malaysia. }\end{array}$ & $\begin{array}{l}\text { The attitude of online shoppers is adversely influenced by } \\
\text { product risk, financial and non-delivery risks. } \\
\text { Convenience risk was shown to have a positive impact on } \\
\text { the mindset of the customer. }\end{array}$ & $\begin{array}{l}\text { The study does not identify the security } \\
\text { factors that impact consumer behavior. }\end{array}$ \\
\hline
\end{tabular}




\begin{tabular}{|l|l|l|l|}
\hline [36] & $\begin{array}{l}\text { Identify the variables that impact users' } \\
\text { paying behavior. }\end{array}$ & $\begin{array}{l}\text { Content quality, peer influence, KOL influence, perceived } \\
\text { interaction, effort expectation, and perceived trust all have } \\
\text { a substantial impact on users' paying behavior. }\end{array}$ & $\begin{array}{l}\text { The findings of the research do not } \\
\text { identify which security variables } \\
\text { influence customer behavior. }\end{array}$ \\
\hline [37] & $\begin{array}{l}\text { Examine the factors that influence the } \\
\text { satisfaction of the younger generation with } \\
\text { digital payment systems. }\end{array}$ & $\begin{array}{l}\text { Perceived risks are shown to have a significant impact on } \\
\text { the behavior intention of using digital payment services. }\end{array}$ & $\begin{array}{l}\text { The research did not identify any factors } \\
\text { relating to the security of digital wallets. }\end{array}$ \\
\hline [42] & $\begin{array}{l}\text { Analyze consumers' intention to utilize digital } \\
\text { payment. }\end{array}$ & $\begin{array}{l}\text { Service quality, perceived risk, perceived security, } \\
\text { perceived simplicity of use, social influence, and } \\
\text { compatibility all have a substantial } \\
\text { impact on consumers' intention to utilize digital payment. }\end{array}$ & $\begin{array}{l}\text { The findings of the study do not reveal } \\
\text { which security variables influence } \\
\text { consumers' purchase decision. In this } \\
\text { case, security was taken into } \\
\text { consideration in a wide sense. }\end{array}$ \\
\hline
\end{tabular}

\section{APPENDIX B}

\begin{tabular}{|c|c|c|c|c|c|}
\hline No. & Issuers (Non-Banks) & Wallet name & No. & Issuers (Non-Banks) & Wallet name \\
\hline 1 & AEON & AEON Member, Plus Card & 25 & Mobile Money International & Money Pin \\
\hline 2 & Alipay Malaysia & Lazada Wallet & 26 & MobilityOne & eM-onei \\
\hline 3 & Axiata Digital eCode & Boost & 27 & MOL AccessPortal & Razer Gold \\
\hline 4 & Bandar Utama City Centre & 1PAY & 28 & MRuncit Commerce & Mcash \\
\hline 5 & Bayo Pay (M) & Construx & 29 & MyEG Alternative & iPayEasy \\
\hline 6 & BigPay Malaysia & BigPay & 30 & TNG Digital Remittance & NAPP (Numoni App) \\
\hline 7 & BLoyalty & B Infinite Pay & 31 & PayPal Pte. Ltd & PayPal \\
\hline 8 & Chevron Malaysia Limited & Caltex StarCard Debit & 32 & Petron Fuel International & Petron Prepaid Fleet Card \\
\hline 9 & DIV Services & Whalet & 33 & Presto Pay & Presto Pay \\
\hline 10 & Fass Payment Solutions & Fasspay & 34 & qBayar & qBayar \\
\hline 11 & Finexus Cards & Visa / Master Prepaid Card & 35 & Raffcomm & e-Info \\
\hline 12 & Fullrich Malaysia & TaPay & 36 & Razer Pay Wallet (M) & Razer Pay \\
\hline 13 & Gkash & Gkash eWallet & 37 & Serba Dinamik IT Solutions & Qwikpay \\
\hline 14 & Google Payment Malaysia & Google Play Gift Card & 38 & Setel Ventures & Setel App \\
\hline 15 & GoPay & GoPay & 39 & ScanPay & MyScanPay \\
\hline 16 & GPay Network (M) & GrabPay & 40 & ShopeePay Malaysia & ShopeePay \\
\hline 17 & Instapay Technologies & Instapay e-Wallet & 41 & SiliconNet Technologies & Sarawak Pay \\
\hline 18 & iPay88 (M) & iPay88 e-Wallet & 42 & SMJ Teratai & eWANG \\
\hline 19 & I-Serve Payment Gateway & Zapp & 43 & Touch 'n Go & Touch 'n Go,Prepaidcard \\
\hline 20 & JuruQuest Consulting & QBpay e-wallet & 44 & TNG Digital & Touch 'n Go eWallet \\
\hline 21 & KiplePay & kiplePay & 45 & U Mobile Services & GoPayz \\
\hline 22 & ManagePay Services & Mpay & 46 & Wavpay Systems & Wavpay \\
\hline 23 & Maxis Broadband & Prepaid Airtime & 47 & WeChat Pay Malaysia & WeChat Pay \\
\hline 24 & Merchantrade Asia & Valyou Wallet & 48 & XOX Com & XOX eWallet \\
\hline
\end{tabular}

APPENDIX C

\begin{tabular}{|l|l|l|}
\hline No. & Banks & Products \\
\hline 1 & AmBank (M) Berhad & Prepaid Card (MasterCard) \\
\hline 2 & Bank of China (M) Berhad & Prepaid Card (China Union Pay) \\
\hline 3 & CIMB Bank Berhad & Prepaid Card (MasterCard) CIMB Pay \\
\hline 4 & Malayan Banking Berhad & QR Pay \\
\hline 5 & RHB Bank Berhad & Prepaid Card (Visa) \\
\hline
\end{tabular}


APPENDIX D

\begin{tabular}{|c|c|c|c|}
\hline Variables & ID & Measurements Items & Values \\
\hline \multirow{3}{*}{ Transaction speed } & TS1 & $\begin{array}{l}\text { Slow online money transaction speed can increase the chances of becoming a fraud victim } \\
\text { while making payments using a digital e-wallet. }\end{array}$ & .816 \\
\hline & TS2 & Fast online money transaction speed improves the security of the digital e-wallet platform. & .847 \\
\hline & TS3 & A faster online money transaction speed gives hackers less time to commit fraud. & .965 \\
\hline \multirow{3}{*}{ Authentication } & AT1 & User authentication has a directly proportional relationship with digital e-wallet security. & .880 \\
\hline & AT2 & $\begin{array}{l}\text { User authentication helps in ensuring the genuine cardholder is in charge while completing } \\
\text { transactions online. }\end{array}$ & .846 \\
\hline & AT3 & User authentication acts as another form of measure to keep scammers away. & .768 \\
\hline \multirow{3}{*}{ Encryption mechanisms } & EM1 & $\begin{array}{l}\text { A good encryption mechanism can prevent the user information from being misused or } \\
\text { hacked. }\end{array}$ & .656 \\
\hline & EM2 & $\begin{array}{l}\text { An encryption mechanism acts as a barrier between the customer and third parties with } \\
\text { malicious intent to steal the customer information. }\end{array}$ & .681 \\
\hline & EM3 & Encrypted data would have no value when stolen by a hacker because the data is encrypted. & .816 \\
\hline \multirow{3}{*}{ Software performance } & SP1 & A software with bugs increases the chances of fraud in the digital wallet. & .939 \\
\hline & SP2 & The higher and better a software's performance, the harder it is for a hacker to break in. & .877 \\
\hline & SP3 & $\begin{array}{l}\text { A software with a slower performance gives a bigger scope for hackers to find the defects in } \\
\text { the system. }\end{array}$ & .916 \\
\hline \multirow{3}{*}{ Privacy details } & PD1 & Information taken from the user can cause security issues perceived risk. & .868 \\
\hline & PD2 & User's information is vulnerable. & 877 \\
\hline & PD3 & The more confidential information stored results in a higher user perceived risk. & .954 \\
\hline \multirow{3}{*}{ Information provided } & IP1 & $\begin{array}{l}\text { Information provided by the digital wallet system can help the user to understand more about } \\
\text { security. }\end{array}$ & .923 \\
\hline & IP2 & $\begin{array}{l}\text { Providing more information about security improves the transparency of an online payment } \\
\text { system. }\end{array}$ & .834 \\
\hline & IP3 & Users will feel more assured and at ease if they are provided with more security information. & .880 \\
\hline \multirow{3}{*}{ Customer satisfaction } & CS1 & Digital wallet services have accelerated my regular activities. & .860 \\
\hline & CS2 & Compared to conventional techniques, the digital wallet is a time-saving system. & .872 \\
\hline & CS3 & I expect that in the near future, I would be using digital wallet systems. & .842 \\
\hline
\end{tabular}

